\title{
Late diagnosis and vulnerabilities of the elderly living with HIV/AIDS*
}

\author{
O diagnóstico tardio e as vulnerabilidades dos idosos vivendo com hiv/aids \\ El diagnóstico tardío y las vulnerabilidades de los ancianos que tienen vih/sida
}

\author{
Rúbia Aguiar Alencar', Suely Itsuko Ciosak ${ }^{2}$
}

\begin{abstract}
* Extracted from the theses "O idoso vivendo com HIV/AIDS: a sexualidade, as vulnerabilidades e os enfrentamentos na atenção básica," School of Nursing, University of São Paulo, 2012.

${ }^{1}$ Assistant Professor, Department of Nursing of the Botucatu Faculty of Medicine of the Universidade Estadual Paulista. Botucatu, SP, Brazil

${ }^{2}$ Associate Professor, Department of Collective Health Nursing, School of Nursing of the University of São Paulo, São Paulo, SP, Brazil.
\end{abstract}

\section{ABSTRACT}

Objective: To identify vulnerabilities of elderly people with HIV/AIDS and the trajectory that they follow until reaching the diagnosis of the disease. Method: Qualitative research conducted in specialized clinics in the state of São Paulo, from January to June 2011. Semi-structured interviews were conducted with 11 elderly people who were found to be infected with the virus at the age of 60 years or older. The interviews were analyzed using content analysis. Results: In this process four categories emerged, then analyzed with reference to the theoretical framework of vulnerability. Conclusion: Late diagnosis of HIV infection or AIDS among the elderly happens in the secondary or tertiary service. Issues related to sexual life of the elderly are only questioned by health professionals after the diagnosis, also the time that condom use becomes absolute. It is believed that the investigation of the vulnerability of the elderly to HIV/AIDS allows for carrying out appropriate interventions for this population.

\section{DESCRIPTORS}

Elderly; Vulnerability; Acquired Immunodeficiency Syndrome; HIV; Delayed Diagnosis; Public Health Nursing.
Correspondence Addressed to:

Rúbia Aguiar Alencar

Departamento de Enfermagem, Faculdade de

Medicina de Botucatu

Distrito de Rubião Junior $\mathrm{s} / \mathrm{n}$

CEP 18618-970 - Botucatu, SP, Brasil

rubia@fmb.unesp.br
Received: 04/01/2014

Approved:11/28/2014 


\section{INTRODUCTION}

Over the years, HIV/AIDS in Brazil has experienced changes in their epidemiological profile, and the elderly have become one of the susceptible groups. According to the Ministry of Health, the infection of older people in most cases occurs through sexual intercourse. This fact is also observed in a study of individuals living with HIV, revealing that $72.8 \%$ contracted the infection through sexual intercourse and had never used a condom during sexual intercourse before knowing of the diagnosis ${ }^{(1)}$.

Sexuality is part of life of any individual at any age, however when related to the elderly population, it is surrounded by myths and beliefs. Even if mistaken, the association of the aging process with the loss of sexual desire ${ }^{(2)}$ is common.

Due to increased life expectancy of the elderly combined with the facilities of modern life, which in this case include hormone replacement and medications to improve sexual performance, they are having the opportunity to rediscover experiences, among them the experience of sexuality ${ }^{(3)}$.

Thus, it is emphasized that sexuality does not make people more vulnerable to contracting HIV, but unprotected sexual practices do, making a presumption extended to all ages, not just the elderly ${ }^{(2)}$.

The problem of late diagnosis of HIV/AIDS among the elderly is linked to three aspects: the elderly are not seen by health professionals as vulnerable to HIV/AIDS; the elderly do not recognize themselves as individuals vulnerable to STD/AIDS; and health professionals end up assigning some symptoms suggestive of opportunistic infections that occur from AIDS to other more significant/common morbidity in the elderly population ${ }^{(4)}$.

Through nursing care to elderly patients living with HIV/AIDS, we found that many diagnoses occurred in the opposite direction of the hierarchy of health services, as rather than the primary service, the secondary level was responsible for diagnostics. This experience raised the following question: How can the vulnerabilities of older people with HIV/AIDS be configured, and what is the route they went through to discover the diagnosis?

This research aimed to identify the vulnerabilities of older people living with HIV/AIDS and their paths taken to discover the diagnosis.

\section{METHOD}

This is a qualitative study done at the Outpatient Service of Infectious Diseases (SAEI) located in a municipality in the state of São Paulo, during the period of January-June 2011.

The study population was elderly at the age of 60 years or older who discovered HIV/AIDS infection when already elderly. In January 2011 there were 527 registered users living with HIV attending care at the outpatient clinic specializing in infectious diseases, and 30 patients were at or over the age of 60 years, and of these 15 had discovered HIV/AIDS when they were already elderly. However, the sample consisted of 11 subjects; seven individuals with AIDS and four with HIV. There were four seniors who did not meet the inclusion criteria, as two were not aware of the infection and presented cognitive impairment, and two refused to participate.

Inclusion criteria were: people aged at or over 60 years old, of both genders, with a positive diagnosis for HIV/ AIDS at 60 years old or more; knowledge of their HIV status and lack of cognitive impairment.

The Mini Mental State Examination (MMSE) was used for the assessment of cognitive function and dementia tracking conducted by the researcher before starting the interview with the elderly. The total score ranges from 0 to 30 points, however as per Suggestions for using the Mini Mental State Examination in Brazil, screening of cognitive status in elderly patients should match the cut-off point for education. Accordingly, 20 and 25 were adopted as cut off points for illiterate and literate, respectively, respecting the median MMSE results for both conditions ${ }^{(5)}$.

From the outpatient clinic specializing in infectious diseases, the researcher contacted the elderly via telephone and set the interview with prior scheduling. It lasted approximately 45 minutes and was conducted in the outpatient offices to maintain the privacy of the respondent.

To collect data, we used an instrument consisting of two parts; the first being a form for socio-demographic information to characterize the participants as to their age, sex, education, profession/occupation, income and with whom they lived. In the second part we used the semi-structured interview technique with the following questions: Tell me how did you find out you were infected with HIV; Tell me what health service did you search out; Did you have any symptoms?; At what point was the (serology) test for HIV requested?; Did any health professionals talk to you about your sex life?

The interviews were recorded and subsequently transcribed. Content analysis was used as the data processing strategy in representational and thematic aspects, and according the proposed stages of: pre-analysis, analysis and material exploration ${ }^{(6)}$.

In possession of empirical categories, these were analyzed with reference to the theoretical framework of vulnerability using the individual, social and programmatic dimensions as categories of analysis to know and understand that the chance of exposure of humans to HIV/AIDS goes beyond the individual aspects; these would include contextual and collective aspects that cause most of susceptibility to infection and illness, and inherently, the availability of various resources for their protection ${ }^{(7)}$.

One of the premises of this reference suggests that the individual and collective aspect approach requires the integration of three axes; defined as individual, social and programmatic vulnerability, as responsible for changing the way we currently understand the AIDS epidemic, especially in Brazil, in helping to overcome the notions of risk group and risky behavior present in the first years of the syndrome ${ }^{(8)}$.

Moreover, the term individual vulnerability degree and the quality of information those individuals have on the health problems, the development of information and its practical application in everyday life ${ }^{(7)}$. Social vulnerability is related to the economic structure, to public policies, especially in education and health, to culture, ideology, gen- 
der, racial and inter-generational relations, religious beliefs and living religiosity, poverty, social exclusion, or even the ways of inclusion that maintain inequality ${ }^{(7-8)}$. On the other hand, programmed vulnerability is associated with the public policy of confronting the disease, as well as the policies and institutions, especially those of health, education, social welfare, justice and culture, which act as elements that reduce, reproduce or increase the conditions of vulnerability of individuals in their contexts ${ }^{(7-8)}$.

In addition, the concept of vulnerability allows a look that includes the user's role as active subjects in the intervention process, both on an individual and social level. For in possession of these conditions, it can elaborate representations to guide its behavior, thereby making it more or less vulnerable to HIV infection or other STDs ${ }^{(7)}$.

It should be noted that this study was approved by the Research Ethics Committee of FMB/UNESP, under protocol 565/10, in view of Resolution 196/96 recommendations. The research process followed the ethical precepts, maintaining the anonymity of the participants as well as the confidentiality of information and requested the signature on an Informed Consent form. With intention of preserving the anonymity of each participant, we chose to identify them as 'Senior' followed by numerical order of the interviews.

\section{RESULTS}

The study included 11 subjects who had positive diagnosis for HIV/AIDS at or older than 60years of age, eight men and three women, a ratio of 2.7 men for every woman, aged 60 to 75 years and with an average of 68 years.

The elderly had low education; one was illiterate, six completed elementary school, two had incomplete secondary education and two had completed high school education. Six were married and the predominant occupations were truck drivers and rural workers (crops/tractors). As expected, there were a higher number of retired and unemployed people during the interviews, totaling seven people with incomes of one to two minimum wages and seven living with wives and children.

The review process according to content analysis resulted in four categories: discovering a late diagnosis of HIV, contradicting primary healthcare services; being perceived as asexual by healthcare professionals; using condoms after the disease was exposed by diagnosis; and diagnosis first revealed to a third party.

Discovering a late diagnosis of HIV contradicting primary healthcare services meant that the diagnosis was revealed to the elderly, often late, by secondary or tertiary healthcare services when this should have occurred in primary care. When the elderly sought primary healthcare service at this level, professionals have not paid attention to soliciting anti-HIV serology tests. The result was a delay of the diagnosis, which took place from 42 days to one year after the onset of signs and symptoms of AIDS. During this period, the diagnosis came during hospitalization or when the patients were seen in emergency rooms, as reported:

$$
\begin{aligned}
& I \text { was at the family healthcare unit, but health } \\
& \text { professionals did not do the right tests; the results }
\end{aligned}
$$

would never come. I started feeling sick and lesions appeared and I also began to lose weight... then I came to the College (Senior 11).

I always had a cold, I've been feeling very weak, and the College doctors did not know what I had. Until I had two pneumonia twice (...) right after that I had herpes zoster (...) I started treatment but it wouldn't heal.(...) After a year, that's when the doctor referred me to another doctor who was a teacher and he said he was going to do all the tests, because they couldn't find out what I had. (...) I was just losing weight (...) when I started doing these tests I was $83 \mathrm{~kg}$ and I went down to $63 \mathrm{~kg}$. Then the antibodies test came back positive. It was in the emergency room (Senior 1).

When HIV was discovered late contradicting the primary health service, these seniors were confronted to reflect on the experience, and thus ended up feeling perceived as asexual beings by health professionals, a condition that they related to from being seen by different generations of professionals, mostly much younger, who were uncomfortable when addressing the sexuality of older people during the consultations. The invisibility of elderly sexuality during their consultations was shown by the fact that health professionals had dialogue with the elderly on their sex lives only after the HIV/AIDS diagnosis, justifying the fear that health professionals have to explore the sexuality of the elderly, as reported:

\section{You know Doc, when a person is younger, some- times one asks certain things about sexuality, but the older people, after 60 years of age, no lon- ger compare themselves with youngsters. We are ashamed (Senior 2).}

No, no, not before. No one ever said anything about these sexuality issues. Ob, they asked after I was sick (Senior 10).

The elderly noticed after late discovery of HIV infection that the experience was not only related to the invisibility factor of the disease to health professionals, but also for only starting to have safer sex with partners after confirming diagnosis. It is for this reason that they started using condoms after the disease was exposed by the diagnosis. All were found to have acquired HIV infection through sexual intercourse, since non-use of condoms is a reality in the lives of seniors. So they reported:

\section{Only today I use condoms with my wife who also has HIV, because it is advised by doctors, right? I've never used condoms in relationships I've had outside of home (...) (Senior 4).}

I had relationships outside of my marriage with another woman while traveling as a truck driver and I never used a condom (...) (Senior 9).

Disbelief in the potential of the elderly was so pronounced that there were cases of health professionals that violated and trampled their rights, as the diagnosis was first revealed to third parties. The elderly had their diagnoses 
revealed to them by their children or wife, who learned the result from the doctor of the healthcare unit which had requested the examination for the patient, and then without the authorization of the senior called the residence of the patient and informed their wife.

I remember ... I got home from a trip, my children and my wife were home - two don't live at home anymore. We started talking and then my son said: Dad, let's talk a little. We sat on the sofa and he said: Do you know what you have? Until then I was not aware and I said No. So they told me that the doctor had called and told that the test tested positive (...) but I didn't know I had done this exam (...) my wife got scary angry. (...) (Senior 3).

\section{DISCUSSION}

Data analysis supported by the theoretical framework of vulnerability allows us to understand the vulnerabilities of older people living with HIV/AIDS.

In 2001, people aged 60 or more accounted for $2.42 \%$ of AIDS cases in Brazil, however, in 2012 this percentage increased to $4.62 \%$. The male / female ratio in 1985 was 26 male cases per female. In 2012, this ratio dropped to 1.7 men for each case in women ${ }^{(9)}$.

The low level of education as found in this study is an important indicator for the increase in rates of infected elderly, since people with less education tend to assimilate information inappropriately, making the acquisition of knowledge about disease inadequate ${ }^{(10)}$. That said, we believe that education is an important variable of social stratification, making individuals with less education more vulnerable to $\mathrm{HIV}^{(10)}$.

Remember that only information about AIDS is not enough for a person to adopt protective behavior, but the lack of basic information directly contributes to increased

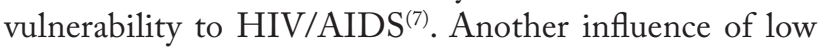
education is related to professional occupation options, as low wages and a lower socioeconomic condition negatively influence access to better quality in the prevention and care of older people with HIV/AIDS ${ }^{(11)}$.

In face of the aging Brazilian population, the National Policy for the Elderly was promulgated in 1994 by Law 8.842/94, and regulated in 1996 by Decree 1.948/96. In 1999, the Ministerial Decree No. 1.395/99 established the National Policy for Elderly Health. In 2002, the organization and implementation of State Networks for Health Care of the Elderly was proposed (Ordinance GM/MS No. 702/2002). In February 2006, the Pact for Health was published through Ordinance/GM No. 399, which includes the Pact for Life. In this document, the health of the elderly appeared as one of six priorities agreed between the three levels of management, triggering the implementation of actions of guiding principles for the reformulation of the National Health Care Policy for the Elderly (PNSPI), established in 2006 by Ordinance GM No. 2528, thus representing an update of the old Ordinance No. 1935/94. The last Act provided that care for the elderly will have a gateway to Primary Care/Family Healthcare, with reference to the network of specialized services of medium and high complexity. In addition, part of the guidelines of this policy is to promote active and healthy ageing. In 2009 through Decree No. 6800, the Coordination of National Policy for the Elderly becomes the responsibility of the Special Secretariat of Human Rights ${ }^{(12)}$.

With policies focusing on active aging working towards health promotion, it is considered essential to address issues related to sexuality ${ }^{(13)}$.

Thus, it is clear that Brazilian public policies recommend that primary care be the service sought by the elderly when requesting service.

In elderly patients, diagnosis is being made at a late stage of the natural history of HIV infection, and the test request for HIV only occurs after extensive research and by exclusion of other diseases, which delays the diagnosis and treatment ${ }^{(14-16)}$.

As many symptoms of the most prevalent diseases in this age group and HIV are similar, to diagnose them separately becomes a complex process. The lack of specificity of symptoms can delay diagnosis up to 10 months, resulting in delayed antiretroviral treatment ${ }^{(13,15)}$.

It is observed that when compared to younger people, those with 50 years or older who have been diagnosed with $\mathrm{HIV}$ are at a more advanced stage of the disease ${ }^{(15-16)}$.

It is essential that early diagnosis for the elderly occurs as they have a more rapid progression of the disease and/or increased risk of progression because the CD4+ cells fall faster at lower levels, making the immune system more deficient in early treatment. Thus, the elderly will have a slower response to antiretroviral therapy (ART) ${ }^{(4)}$, and HIV accelerates the progression of comorbidities among the elderly ${ }^{(17)}$.

Although health professionals reporting the importance of the application of anti-HIV testing, it was observed that this practice does not qualify as an effective measure in everyday care for the elderly population ${ }^{(17)}$.

From the observation that the diagnosis of HIV/AIDS occurs late in the elderly ${ }^{(14,18-19)}$, it is believed that the number of older people infected with HIV is underestimated, since it is a predicted diagnosis for which health professionals do not conduct the tests, leading to errors, difficulties and / or delays of the diagnosis which can cause suffering and unnecessary deaths ${ }^{(20)}$.

Health professionals do not ask about sexuality or STD/AIDS issues during their consultations with the elderly ${ }^{(13-14,21)}$ and this fact is also evidenced in this study. The information is transmitted only through printed material and at no time is it addressed in consultation and/or lectures, demonstrating the fragility of senior care ${ }^{(3)}$.

It is known that given the increase in life expectancy, several generations live simultaneously. Generations are continually constructed, deconstructed and reconstructed, and the relationship between them is also always being reformed. The myths and prejudices in the relationship between elderly and health professionals when it comes to sexuality suggest that if the medical professional understands that sexuality is intrinsic to human nature and consider it as something natural in the life of the elderly, the discussion of issues related to it will be easier, thereby mak- 
ing the request of HIV testing become a routine procedure similar to what occurs in addressing younger patients ${ }^{(20)}$.

In this way, the approach to the sexual life of the elderly will not be happening only after the diagnosis of HIV/ AIDS, as observed in this study.

It is observed that what happens is fragmented care because many actions, such as the prevention of STD/AIDS, the approach to discuss sexuality, and the HIV serology request are not being performed ${ }^{(3,14,22)}$.

However, the perception that health professionals have about elderly sexuality is directly reflected to the way they approach this subject with their patients. Since sexuality is inherent to humans and manifests itself throughout life, it is understandable that the professional considers their own values in addressing the sexuality of their patient, given the difficulty of being totally neutral on this subject. The acquisition of knowledge on the subject which should happen during their training contributes to the reduction of undue and inappropriate attitudes of professionals in dealing with patients ${ }^{(23)}$.

However, the deficiency in the theme of sexuality in the elderly ${ }^{(14)}$ is observed in the training of health professionals in undergraduate and post-graduate courses. This fact is exemplified by not having specific disciplines for the teaching human sexuality ${ }^{(23)}$ in the curriculum of São Paulo state public nursing schools.

As for condom use, studies of elderly people living with HIV/AIDS revealed results similar to the present study as it was also found that older people did not use a condom before learning of their diagnosis ${ }^{(24)}$.

Many elderly people were encouraged to have multiple partners in their youth as a sign of masculinity and without any appeal to condom use ${ }^{(10)}$. In Brazilian society, some cultural issues like infidelity and the multiplicity of partners are still socially accepted as something natural in the trajectory of a man's life, especially in the generation of 60 years and even so nowadays ${ }^{(25)}$.

Interviews with men and women about condom use shows that the subjects believe that loyalty and trust are responsible for ensuring safe sex for the couple, not the use of condoms. Thus, it was emphasized that when there are feelings, it is unnecessary to use protection ${ }^{(26)}$.

Ratifying the above information, marriage or a stable relationship is often highlighted by women as a protective factor against HIV because they believe in a romantic view; that loyalty, respect, trust and complicity would be protecting the couple, which can lead to the disuse of condoms ${ }^{(2,27)}$.

However, the expression of confidence means different things to men and women. For men it is related to the fidelity of the partner, sexual exclusivity. For women it is linked to the belief that their partner uses condoms in extramarital relations and consequently does not use protection at home ${ }^{(28)}$.

In this sense, the characteristics of political, economic and social contexts are responsible for making women more vulnerable to HIV, especially the elderly, due to the characteristics of their emotional-sexual relationships, as they have low risk perception and do not see themselves as vulnerable ${ }^{(29)}$.

Therefore, we emphasize the importance of understanding the attitudes and practices of elderly in relation to the experience of their sexuality, which enables them to perform interventions that reduce the vulnerability of this segment of the population. This requires that dialogue occurs between the health professional and the elderly.

Among the rights of the elderly is the need to better explain the reason for the examination request to the patient, as well as to request permission to perform it by requesting the consent form signed.

Normative Instruction No. 1626 of July 10, 2007, regulates the procedures and practices of consensual approach to users who seek health services in order to carry out the antiHIV testing and other STDs ${ }^{(30)}$. It is therefore established in this document that the application of anti-HIV testing can only be performed after the health service presents the user with the Informed Consent Agreement for the approach.

Comprehensive care for the elderly does not only cover the aspects of prevention, but also the accountability, bond, commitment and humanization ${ }^{(25)}$. Everyone has the right to grow old with dignity, to have access and opportunities consistent with the possibilities of the elderly. Furthermore, it is known that aging does not occur in the same way for all people. Thus, understanding the elderly as to the subject of their daily lives and rights is the necessary basis to identify and transform social relations that produce health problems and the means to overcome them ${ }^{(11)}$.

This study showed through reports of elderly living with HIV/AIDS interpreted through the concept of vulnerability that the difficulty of early diagnosis of HIV/AIDS among the elderly is directly related to the fact that these individuals are perceived as asexual by health professionals, and as a result the request of anti-HIV testing in primary care is not part of the conduct of the professionals who attend them. In addition, it is observed that these seniors do not realize that they are vulnerable to HIV/AIDS, evidenced when they report that they used condoms only after the diagnosis.

Regarding the possible impact of the knowledge produced by this study in health practices, it can be stated that the results provide backing for health professionals to rethink their approach during the consultations to the elderly and to address issues related to the sexual lives of them by offering openness to dialogue as seen in another study ${ }^{(14)}$, which will enable them with knowledge on the vulnerabilities of older people.

This qualitative study has limitations because it precludes causal inferences. Thus, one cannot generalize the results to other municipalities and health services that attend older people living with HIV/AIDS.

\section{CONCLUSION}

Late diagnosis of HIV/AIDS is still an unfortunate reality among the elderly that occurs even when there are signs and symptoms suggestive of AIDS, and only comes after an exhausting route among health services. Although they have primary care service as the first option, the outcome of their diagnosis is typically occurring in secondary or tertiary health services.

Older people are viewed as asexual by health professionals, as the dialogue on issues related to sexuality only 
happens after the diagnosis of HIV/AIDS. Another fact that is realized only after diagnosis is the use of condoms, which even then was not part of their lives.

It is necessary for health professionals to open dialogue with their elderly patients on issues related to sexuality without judgement. In order to operationalize the concept of vulnerability in the context of elderly health, it is believed that a possible strategy is the development of an instrument that encompasses issues related to individual, social and programmatic vulnerability. This instrument when applied by nurses or primary care physicians during the consultation with elderly can assess the vulnerability of this specific group to HIV/AIDS, and therefore propose appropriate measures according to the needs of each individual with the request of anti-HIV serology among them.
It is noteworthy that requesting HIV serology does not reduce the number of infected, but allows elderly people with this infection to start treatment earlier, thereby promoting improvements during the course of infection. Another important point is that if the professionals perceive the elderly as a sexually active individuals, they may open more dialogue on issues of sexuality more naturally, guiding and educating them about prevention. Thus, there may be a decrease in HIV cases among the elderly.

Therefore, it is necessary that the educational institutions and training offered to health professionals working in primary care address this content on the health of the elderly, focusing on sexuality. The emancipation of the elderly will only happen if this change occurs in the views of health professionals.

\section{RESUMO}

Objetivo: Identificar as vulnerabilidades de idosos com HIV/aids e o caminho percorrido por eles até o diagnóstico da doença. Método: Pesquisa qualitativa conduzida em ambulatório especializado no interior do Estado de São Paulo, de janeiro a junho de 2011. Realizouse entrevista semiestruturada com 11 idosos que se descobriram infectados com o vírus com idade igual ou superior a 60 anos. As entrevistas foram analisadas utilizando a análise de conteúdo. Resultados: Desse processo emergiram quatro categorias, que foram analisadas à luz do referencial teórico da vulnerabilidade. Conclusão: $\mathrm{O}$ diagnóstico tardio da infecção por HIV ou aids entre os idosos acontece no serviço secundário ou terciário. Questões relacionadas à vida sexual dos idosos só são questionadas pelos profissionais de saúde após o diagnóstico da doença, momento também em que o uso do preservativo se torna concreto. Acredita-se que a investigação da vulnerabilidade do idoso ao HIV/aids possibilita realizar intervenções pertinentes a essa população.

\section{DESCRITORES}

Idoso; Vulnerabilidade; Síndrome de Imunodeficiência Adquirida; HIV; Diagnóstico Tardio; Enfermagem em Saúde Pública.

\section{RESUMEN}

Objetivo: Identificar las vulnerabilidades de los ancianos con VIH/SIDA y el camino recorrido por ellos hasta el diagnóstico de la enfermedad. Método: Investigación cualitativa conducida en ambulatorio especializado en el interior del Estado de São Paulo, de enero a junio de 2011. Se llevó a cabo entrevista semiestructurada con 11 añosos que se descubrieron infectados con el virus en edad igual o superior a 60 años. Las entrevistas fueron valoradas utilizándose el análisis de contenido. Resultados: De ese proceso surgieron cuatro categorías, las que se analizaron a la luz del marco de referencia teórico de la vulnerabilidad. Conclusión:wwEl diagnóstico tardío de la infección por VIH o SIDA entre los ancianos ocurre en el servicio secundario o terciario. Cuestiones relacionadas con la vida sexual de los ancianos sólo las cuestionan los profesionales de salud luego del diagnóstico de la enfermedad, momento también en que el uso del preservativo se hace concreto. Se cree que la investigación de la vulnerabilidad del anciano al VIH/SIDA posibilita realizar intervenciones pertinentes a dicha población.

\section{DESCRIPTORES}

Anciano; Vulnerabilidad; Síndrome de Inmunodeficiencia Adquirida; VIH; Diagnóstico Tardío; Enfermería en Salud Pública.

\section{REFERENCES}

1. Bertoncini BZ, Moraes KS, Kulkamp IC. Comportamento sexual em adultos maiores de 50 anos infectados pelo HIV. J Bras Doenças Sex Transm. 2007;19(2):75-9.

2. Andrade HAS, Silva SK, Santos MIPO. Aids em idosos: vivências dos doentes. Esc Anna Nery. 2010;14(4):712-9.

3. Laroque MF, Affeldt AB, Cardoso DH, Souza GL, Santana MG, Lange C. Sexualidade do idoso: comportamento para a prevenção de DST/ AIDS. Rev Gaúcha Enferm. 2011;32(4):774-80.

4. Brañas F, Serra JA. Infeccíon por el virus de la inmunodeficiencia humana en el anciano. Rev Esp Geriatr Gerontol. 2009;44(3):149-54.

5. Santos CS, Cerchiari EAN, Alvarenga MRM, Faccenda O, Oliveira MAC. Avaliação da confiabilidade do mini-exame do estado mental em idosos e associação com variáveis sociodemográficas. Cogitare Enferm. 2010;15(3):406-12.

6. Bardin L. Análise de conteúdo. Lisboa: Edições 70; 2009.

7. Ayres JR, Paiva V, França Junior I. Conceitos e práticas de prevenção: da história natural da doença ao quadro da vulnerabilidade e direitos humanos. In: Paiva V, Ayres JR, Buchalla CM. Vulnerabilidade e direitos humanos: prevenção e promoção da saúde: da doença à cidadania. Curitiba: Juruá; 2012. p.71-94. 
8. Nichiata LYI, Bertolozzi MR, Takahashi RF, Fracolli LA. The use of the "vulnerability" concept in the nursing area. Rev Latino Am Enfermagem 2008;16(5):1326-30.

9. Boletim Epidemiológico Aids e DST. Brasília: Secretaria de Vigilância em Saúde, Departamento de DST, Aids e Hepatites Virais. $2013 ; 2(1): 1-61$.

10. Silva HR, Marreiros MOC, Figueiredo TS, Figueiredo MLF. Características clínico-epidemiológicas de pacientes idosos com aids em hospital de referencia, Teresina-PI. Epidemiol Serv Saúde. 2011;20(4):499-507.

11. Pottes FA, Brito AM, Gouveia GC, Araújo EC, Carneiro RM. Aids e envelhecimento: características dos casos com idade igual ou maior que 50 anos em Pernambuco, de 1990 a 2000. Rev Bras Epidemiol. 2007;10(3):338-51.

12. Brasil. Ministério da Saúde; Secretaria de Atenção à Saúde, Departamento de Ações Programáticas e Estratégicas. Atenção à saúde da pessoa idosa. Brasília; 2010.

13. São Paulo (Estado). Secretaria de Estado da Saúde de São Paulo; Centro de Referência e Treinamento em DST/Aids. Documento de diretrizes para prevenção das DST/Aids em idosos. Bepa. 2011;8(92):15-23.

14. Slinkard MS, Kazer MW. Older adults and HIV and STI screening: the patient perspective. Geriatr Nurs. 2011;32(5):341-9.

15. Ellman TM, Sexton ME, Warshafsky D, Sobieszczyk ME, Morrison EAB. A forgotten population: older adults with newly diagnosed HIV. AIDS Patient Care STDs. 2014;28(10):530-6.

16. Linley L, Prejean J, An Q, Chen M, Hall HI. Racial/ethnic disparities in HIV diagnoses among persons aged 50 years and older in 37 US States, 2005-2008. Am J Public Health. 2012;102(8):1527-34.

17. Nguyen N, Holodniy M. HIV infection in the elderly. Clin Interv Aging. 2008;3(3):453-72.

18. Liu H, Lin X, Xu Y, Chen S, Shi J, Morisky D. Emerging HIV epidemic among older adults in Nanning, China. AIDS Patient Care STDS. 2012;26(10):565-7.

19. Rodriguez-Penney AT, ludicello JE, Riggs PK, Doyle K, Ellis RJ, Letendre SL, et al. Comorbidities in persons infected with HIV: Increased burden with older age and negative effects on health-related quality of life. AIDS Patient Care STDS 2013;27(1):5-16.

20. Alencar RA, Ciosak SI. Early diagnosis of HIV in the elderly population: a brief review of the literature. Online Braz J Nurs [Internet]. 2010 [cited 2014 Jan 10];9(2). Available from: http://www.objnursing.uff.br/index.php/nursing/article/view/2989

21. Greene M, Justice AC, Lampiris HW, Valcour V. Management of human immunodeficiency virus infection in advanced age. JAMA. 2013;309(13):1397-405.

22. Driemeier M, Andrade SMO, Pontes ERJC, Paniago AMM, Cunha RV. Vulnerability to AIDS among the elderly in an urban center in central Brazil. Clinics (São Paulo). 2012;67(1):19-25.

23. Alencar RA. Ciosak SI, Bueno SMV. Training of academic nurses: the need to place in the curriculum of the subject of human sexuality. Online Braz J Nurs [Internet]. 2010 [cited 2014 Jan 15];9(2). Available from: http://www.objnursing.uff.br/index.php/nursing/article/view/2991

24. Lovejoy TI, Heckman TG, Sikkema KJ, Hansen NB, Kochman A, Suhr JA, et al. Patterns and correlates of sexual activity and condom use behavior in persons 50-plus years of age living with HIV/IDS. AIDS Behav. 2008;12(6):943-56.

25. Santos AFM, Assis M. Vulnerabilidade das idosas ao HIV/AIDS: despertar das políticas públicas e profissionais de saúde no contexto da atenção integral: revisão de literatura. Rev Bras Geriatr Gerontol. 2011;14(1):147-57.

26. Madureira VSF, Trentini M. Da utilização do preservativo masculino à prevenção de DST/AIDS. Ciênc Saúde Coletiva. 2008;13(6)1807-16.

27. Silva CM, Vargens OMC. Women's perception about female vulnerability to STD and HIV. Rev Esc Enferm USP. 2009;43(2):401-6.

28. Garcia S, Souza FM. Vulnerabilidades ao HIV/aids no contexto brasileiro: iniquidades de gênero, raça e geração. Saúde Soc. 2010;19 Supl. 2:9-20.

29. Silva CM, Lopes FMVM, Vargens OMC. A vulnerabilidade da mulher idosa em relação a Aids. Rev Gaúcha Enferm. 2010;31(3):450-7.

30. Brasil. Ministério da Saúde. Instrução normativa n. 1.626, de 10 de julho de 2007. Regulamenta os procedimentos e condutas para a abordagem consentida a usuários que procuram os serviços de saúde com vistas a realizar testes de HIV e outras DST, bem como aos que não comparecem ao tratamento já em curso [Internet]. Brasília; 2007 [citado 2013 jul. 22]. Disponível em: http://bvsms.saude.gov.br/bvs/ saudelegis/gm/2007/in1626_10_07_2007.html 